\title{
Stable Expression of Basic Fibroblast Growth Factor in Chloroplasts of Tobacco
}

\author{
Yun-Peng Wang ${ }^{1}$, Zheng-Yi Wei ${ }^{1}$, Xiao-Fang Zhong ${ }^{1}$, Chun-Jing Lin ${ }^{1}$, Yu-Hong Cai ${ }^{2}$, Jian Ma ${ }^{3}$, \\ Yu-Ying Zhang ${ }^{1,4}$, Yan-Zhi Liu ${ }^{1}$ and Shao-Chen Xing ${ }^{1, *}$
}

Received: 4 November 2015; Accepted: 15 December 2015; Published: 23 December 2015

Academic Editors: Setsuko Komatsu and Marcello Iriti

1 Jilin Provincial Key Laboratory of Agricultural Biotechnology, Agro-Biotechnology Research Institute, Jilin Academy of Agricultural Sciences, No. 1363, Shengtai st., Changchun 130033, China; wangypbio@163.com (Y.-P.W.); weizy@cjaas.com (Z.-Y.W.); zhongxf@cjaas.com (X.-F.Z.); lincj@cjaas.com (C.-J.L.); yuying0609@126.com (Y.-Y.Z.); liuyz_g@126.com (Y.-Z.L.)

2 Institute of Agricultural Quality Standard and Testing Technology, Jilin Academy of Agricultural Sciences, No. 1363, Shengtai st., Changchun 130033, China; yhcai64@163.com

3 Faculty of Agronomy, Jilin Agricultural University, No. 2888, Xincheng st., Changchun 130118, China; majian19790106@163.com

4 College of Biological Sciences, China Agricultural University, No. 2 West Yuanmingyuan Road, Beijing 100094, China

* Correspondence: xingsc@cjaas.com; Tel.: +86-431-8706-3121; Fax: +86-431-8706-3080

\begin{abstract}
Basic fibroblast growth factor (bFGF) is a multifunctional factor in acceleration of cell proliferation, differentiation and transference, and therefore widely used in clinical applications. In this study, expression vector $\mathrm{pWX}-\mathrm{Nt} 03$ harboring a codon-optimized bFGF gene was constructed and introduced into the tobacco chloroplasts by particle bombardment. After four rounds of selection, $b F G F$ was proved to integrate into the chloroplast genome of regenerated plants and two of four transgenic plants were confirmed to be homoplastomic by PCR and Southern hybridization. ELISA assay indicated that $b F G F$ represented approximately $0.1 \%$ of total soluble protein in the leaves of transplastomic tobacco plants. This is the first report of $b F G F$ expression via chloroplast transformation in model plant, providing an additional option for the production of chloroplast-produced therapeutic proteins.
\end{abstract}

Keywords: tobacco; chloroplast; genetic transformation; basic fibroblast growth factor; green fluorescent protein

\section{Introduction}

Fibroblast growth factors (FGF) are a large family of heparin-binding protein mitogens, with potential therapeutic utilities due to their broad target cells specificity. Twenty three different FGFs have been described thus far [1]. One FGF, basic fibroblast growth factor (bFGF or FGF2), a single-subunit protein with a molecular weight of $\sim 17 \mathrm{kDa}$ and a $\mathrm{pI}$ of 9.6, was first cloned from the bovine brain and pituitary in 1978 [2].

bFGF acts to accelerate cellular proliferation, differentiation and transference [3-5]. Recombinant bFGF is highly desirable in the marketing due to its critical role in the growth of blood vessels, wound healing, tissue regeneration and nerve system [6-8] and many attempts have been made to meet the great demand over the past few decades. Currently bFGF is produced via genetic engineering technology in several systems, from conventional microbial expression systems like Escherichia coli (E. coli) [9,10], Bacillus subtilis [11] and yeast [12,13], to insect cells [14]. More importantly, two main crops, soybean and rice, were reported to express functional recombinant bFGF specifically in seeds 
by Agrobacterium-mediated transformation $[15,16]$. However, the insolubility and biological activity of target proteins would likely be an intractable obstacle for microbial [17] and plant-produced [16] platform to lag the further application when high level of protein expression was achieved. Plant-based production of therapeutic proteins or antigens can be cost-effective, as, unlike microbial systems, it does not require sterile laboratories or production equipment $[18,19]$. But, thus far the efficiency of plant nuclear transformation with many genes remains low, producing low protein yields complicated by gene silencing and unstable inheritance [20]. Moreover, pollen-mediated transgene flow has drawn significant attention due to its potential impact on biodiversity [21]. Chloroplast transformation will be likely to overcome those disadvantages due to the features of higher expression, generally soluble proteins and mostly maternal inheritance, although some challenges such as protein degradation, pleiotropic effects, time-consuming homoplasmic selection are still the main hurdles for most of plants and need to be addressed [22,23]. Since tobacco was firstly engineered via chloroplast transformation, plastid transformation has drawn more attention, achieving high-level expression, gene-stacking, no gene silencing, and even facilitating successful transfer of whole metabolic pathways to plastids [24].

In this study, we engineered tobacco plants to express bFGF via plastid transformation. To our knowledge, this is the first report of bFGF expressed via plastid transformation and therefore provides a novel alternative of bFGF expression.

\section{Results}

\subsection{Construction of Expression Vector and Functional Verification}

An expression vector named pWXL-Nt03 for tobacco chloroplast transformation was constructed based on previously published protocol used in our laboratory [25] with two modifications (Figure 1). The homologous fragment from alfalfa was replaced with one from the tobacco plastid genome, and the codon-optimized $b F G F$ gene was inserted into the vector multiple cloning site of the vector. The vector was verified by sequencing.

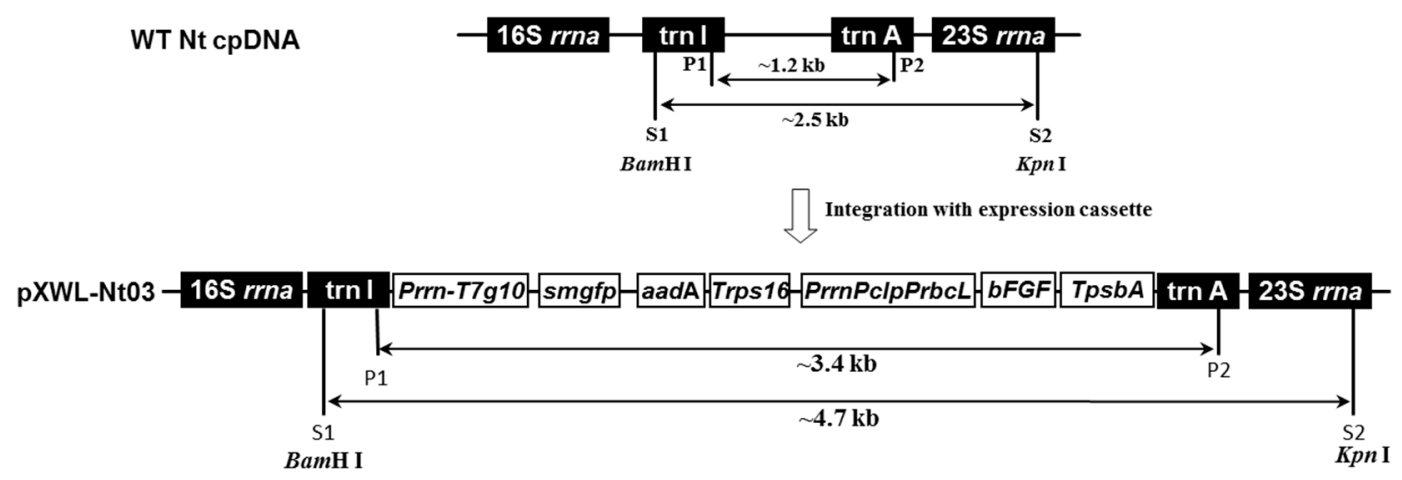

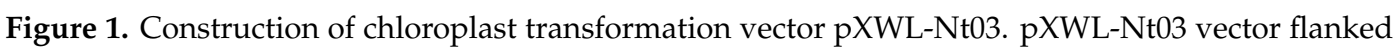
with chloroplast regions of $16 S-\operatorname{trnI}$ and $\operatorname{trn} A$-23S comprised a synthetic expression cassette containing the smgfp reporter gene and aadA selectable marker gene. These two genes were jointly driven by the Prrn-T7g10 promoter and the terminator was 3' untranslated regions (UTR) rps16 (Trps16). The target basic fibroblast growth factor (bFGF) gene was driven by the fusion promoter PrrnPclpPrbcL previously described [26] and $p s b A$ 3' UTR as terminator (TpsbA). P1/P2 and S1/S2 indicated the primers used for PCR and digestion sites for Southern blot analysis, respectively. A 3.4 kb fragment was amplified for transplastomic plants, but a $\sim 1.2 \mathrm{~kb}$ fragment in wild-type tobacco chloroplast DNA (WT Nt cpDNA) without expression cassette. Similarly, total DNA was digested by BamH I and Kpn I for Southern blot analysis. A $\sim 4.7 \mathrm{~kb}$ signal was hybridized for transplastomic plants, but only a $\sim 2.5 \mathrm{~kb}$ for untransformed plants. 
The chloroplast originated from a prokaryote and thus contains prokaryotic protein synthesis machinery. The specific expression vector for chloroplast transformation was therefore generally transferred into prokaryotic system like E. coli to test its genetic construction and function [27]. After the MACH 1, an E. coli strain, was transformed with this vector following the heat shock protocol, the overnight-cultured cells were collected by centrifugation. The pellet was observed to appear green in color, indicating the successful expression of green fluorescent protein (GFP) in transformed bacterial cells. This observation suggested that the other genes within the same expression cassette will play their roles in prokaryotic-like chloroplast expression system.

\subsection{Tobacco Chloroplast Transformation and Homoplastomic Selection}

Young leaves were placed on the Murashige and Skoog (MS) medium with adaxial side down, cultured for $4 \mathrm{~h}$ in the dark and bombarded. The bombarded leaves were cultured in the dark at $26{ }^{\circ} \mathrm{C}$ for 3 days before being cut into $5 \mathrm{~mm} \times 5 \mathrm{~mm}$ pieces and transferred into the selection media containing $500 \mathrm{mg} / \mathrm{L}$ of spectinomycin. Selection media was replaced every 3 weeks. Forty-three resistant transformants were regenerated in selection media, and integration of the expression cassette was verified by PCR. Young leaves from PCR-positive shoots were cut into pieces and placed abaxial side down in selective media and cultured for two to three additional regeneration cycles to obtain homoplastomic plants (Figure 2). Seeds were harvested from homoplastomic tobacco plants and sowed in soil until to $\mathrm{T}_{3}$ generation.
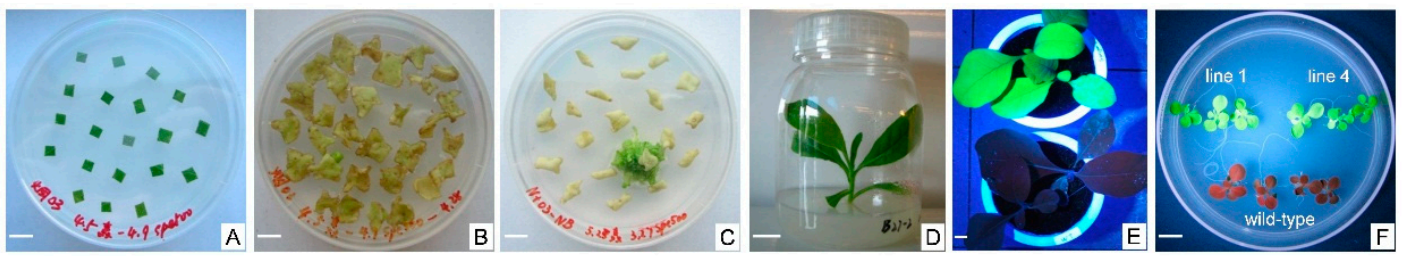

Figure 2. Procedure for homoplastomic selection after chloroplast transformation of tobacco. (A) Bombarded leaves were cut into pieces for selection; (B) Resistant shoots appear while most leave pieces bleached on antibiotic medium; (C) Surviving antibiotic resistant shoots; (D) Regenerated plantlet after first round of selection; (E) GFP expression in $\mathrm{T}_{0}$ transplastomic tobacco with green color and chlorophyll autofluorescence with red color under ultraviolet (UV) lamp; (F) GFP expression in $\mathrm{T}_{3}$ homoplastomic tobacco seedlings, line 1 and line 4 , and wild-type control under UV lamp. Scale bars $=1 \mathrm{~cm}$.

\subsection{Molecular Characterization of $T_{0}$ Transplastomic Plants}

After four rounds of selection, antibiotic resistant shoots were obtained and transferred to new media without phytohormone for rooting. Integration of the foreign expression cassette into the plastid genome of transformants was verified by PCR. As shown in Figure 3A, two putative transgenic plants were homoplastomic with the single band of $\sim 3.4 \mathrm{~kb}$, but an additional $\sim 1.2 \mathrm{~kb}$ band in lanes 2 and 3 indicated the heteroplastomic status of other two plants. Both hetero-/homoplastomic plants displayed normal phenotypes compared with wild-type plants under greenhouse condition.

Total DNA was isolated from the leaves of $\mathrm{T}_{0}$ transgenic and wild-type plants and integration of the $b F G F$ gene into the tobacco plastid genome was confirmed by Southern blot. As indicated in Figure $3 \mathrm{~B}$, the single $\sim 4.7 \mathrm{~kb}$ band in lane 1 and 4 implied homoplastomic status, whereas lanes 2 and 3 displayed an additional $\sim 2.5 \mathrm{~kb}$ band, identically amplified from wild-type plants, indicating heteroplastomic status.

Northern blot was carried out to investigate the transcript level of $g f p$ and $b F G F$. As shown in Figure 3C, no strong differences of hybridization signal intensity was observed between $g f p$ and $b F G F$ genes, indicating the similar accumulation of mRNAs before translation into proteins unless the hybridizations are obviously probe sequence dependent. 
Western blot revealed proteins of approximately $17 \mathrm{kDa}$ in lanes 1 to 4 , representing bFGF expression in the four $\mathrm{T}_{0}$ transgenic lines (Figure $3 \mathrm{D}$ ) of identical size to commercially produced bFGF. As expected, no signal was observed for wild-type plant.
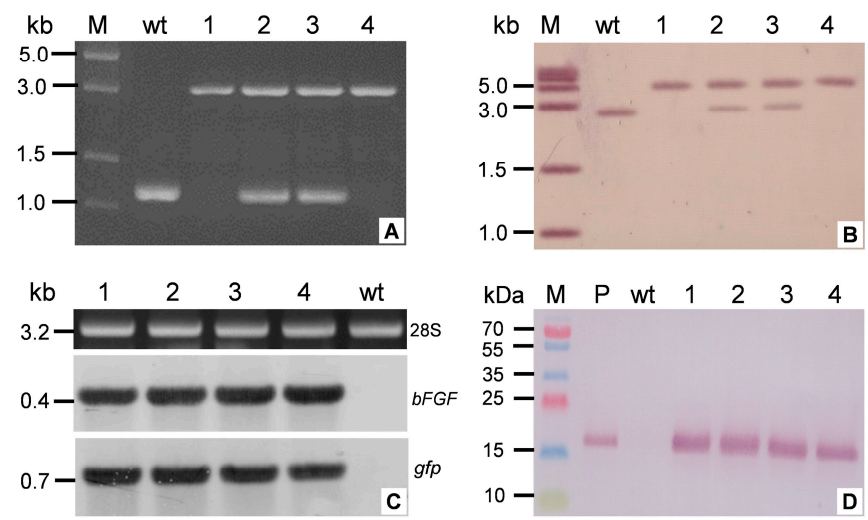

Figure 3. Molecular testing of $T_{0}$ transplastomic plants. (A) PCR analysis of integration of the expression cassette into transgenic plants. M, DNA molecular marker; Lanes 1-4: $\mathrm{T}_{0}$ putative transgenic plants; (B) Southern blot analysis. M, DNA molecular marker; Lanes 1-4: the leaves of $\mathrm{T}_{0}$ putative transgenic plants. The single $4.7 \mathrm{~kb}$ band in lanes 1 to 4 indicated homoplastomic status due to the insertion of foreign expression cassette, whereas lanes 2 and 3 with an additional $2.5 \mathrm{~kb}$ band, amplified from wild-type plants, indicating heteroplastomic status; (C) Northern blot analysis for $b F G F$ (middle) and $g f p$ (bottom) mRNAs. The ethidium bromide-stained gel of $28 \mathrm{~S}$ band of total RNA is shown in the top as a loading quantitative control. wt is untransformed tobacco as negative control; (D) Western blot for determining the expression of bFGF in $\mathrm{T}_{0}$ transplastomic plants. Expression of bFGF (17 kDa) is observed in the leaves of four transgenic plants (lanes 1-4), but absent in the leaves of a wild-type plant (wt). Commercial bFGF protein $(\mathrm{P})$ served as positive control. $\mathrm{M}$ is protein marker.

\subsection{Measurement of bFGF and GFP Expression in $T_{0}$ Transformed Plants by ELISA}

Total soluble protein (TSP) was extracted from the leaves of $\mathrm{T}_{0}$ transformed plants to quantify the expression of bFGF and GFP by ELISA. In the four transgenic plants bFGF represented between $0.095 \%$ and $0.106 \%$ of TSP from mature leaves (Figure $4 \mathrm{~A}$ ) and much lower expression in young and old leaves (data not shown), indicating a far lower level of bFGF expression than GFP, which the maximum average expression level can reach up to $22.343 \%$ of TSP in mature leaves. The average expression in young and old leaves is $13.441 \%$ and $1.947 \%$ of TSP, relatively lower than mature leaves (Figure 4B).
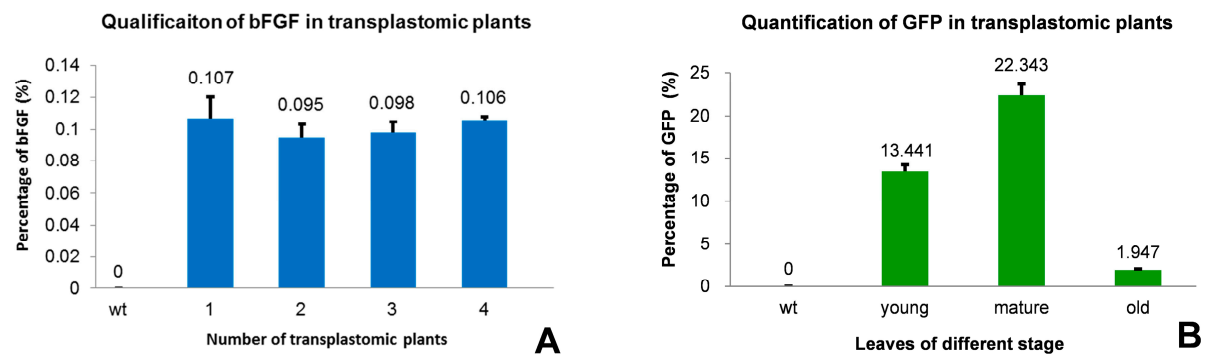

Figure 4. Quantification of bFGF and GFP in transgenic tobacco plants. (A) Level of bFGF expression in the leaves of four independent transgenic plants was shown in relation to total soluble protein (mean $\pm \mathrm{SD}$ ). 1-4, independent transplastomic plants; wt, Wild-type plant; (B) Level of GFP expression in young, mature and old leaves of transplastomic plants; wt, Wild-type plant. All measurements were made in triplicate. 


\section{Discussion}

Plant-made pharmaceuticals (PMPs), both nuclear and plastid stable transformation, offer several unique advantages over microorganism and mammalian systems, allowing production in large scales but low cost and lack of endotoxins and pyrogens. This had been recognized as a promising potential method for the production of therapeutic proteins [28,29]. Some plants like peas, which have high protein content and excellent storage capacity, are an ideal platform for production of pharmaceuticals [30]. Although no plastid-produced products have been used in clinical trials yet, vaccines produced by nuclear transformation of plants or TMV-based transient expression in plants have been tested in the clinic [23,29].

bFGF has previously been expressed by nuclear transformation system and the yield, $2.3 \%$ TSP in soybean seeds and $9.55 \%$ TSP in rice seeds $[15,16]$, is rather higher than the production in the present experiment, but considering that: (1) the biomass of tobacco mature leaves with average yield of 2.7 tons per hectare [31]; (2) the tobacco needs approximately 40-50 days from seed to fully-expanded leaves; and (3) it is practicable to harvest five to seven times annually under field condition depending on the growing season, the bFGF productivity of transgenic tobacco might be more competitive compared with soybean and rice. The homoplasmic expression of bFGF was achieved in this study, but accumulation needs to be enhanced greatly (Figure 4A). To do this, some possible measures could be taken including $\mathrm{N}$-terminus and tag-added modification [32]. In addition, chloroplast-expressed proteins are generally soluble [22], making this system more attractive for solving the insolubility of protein expressed by conventional nuclear transformation [16]. This study can also pave the way for bFGF expression in other plants, especially vegetables which is feasible for oral delivery without fermentation, purification, cold storage and transportation [22].

Another puzzling question is the expression of GFP which located in the same cassette with bFGF. GFP expression demonstrated far higher level (Figure 4B) than bFGF. Since all of the possible parameters were considered to maintain the uniformity in Northern hybridization operation except the length of two probe sequences, the similar signal intensity should reflect the amount of mRNA (Figure 3C). The strong disparity in accumulation of two proteins therefore could not be explained by their respective mRNA stability alone. It is reported that protein accumulation in transplastomic plants was very likely controlled by post-translational regulation at the level of protein stability [33-35] and three factors were experimentally recognized to affect their stability, including the penultimate $\mathrm{N}$-terminal amino acid residue, an $\mathrm{N}$-end rule-like protein degradation pathway and additional sequence determinants in the N-terminal region as well [32]. In our study, the different production of bFGF and GFP is somehow caused by protein degradation as there is no detectable difference was visible at least in transcriptional level. We also cannot exclude the possibility of other factors. For example, the initiation of translation might be affected strongly by $3^{\prime}$ UTRs [36] and therefore the 3'UTR in this study, the leader sequences of $g 10$ and $c l p P$ genes, might contribute the gap of translation initiation efficiency to a certain extent [37]. In addition, the small-molecule bFGF, unlike well-known stable GFP, is reported to be unstable in the presence of many proteases [38]. To improve the stability of recombinant protein, the small ubiquitin-related modifier fusion could be superior to glutathione $S$-transferase in enhancement of the expression and solubility of difficult-to-express proteins [39]. According to the proposed hypothesis [32], future attempts to express bFGF in tobacco plastids may employ artificially optimized tag(s) to promote the solubility and stability of the products with less energy consumption of the host cells.

\section{Materials and Methods}

\subsection{Plant Materials}

Tobacco (Nicotiana tabacum cv. Petit Havana) seeds were surface-sterilized and grown on half-strength MS medium supplemented with $8 \mathrm{~g} / \mathrm{L}$ agar and $30 \mathrm{~g} / \mathrm{L}$ sucrose with a 16-h light/8-h dark photoperiod. Young leaves were used for plastid DNA extraction and transformation. 


\subsection{Vector Construction for Chloroplast Transformation}

According to the complete tobacco chloroplast genome sequences (accession number: NC-001879), two primers (P1: ACAGAGGATGCAAGCGTTAT and P2: CACTGAGCGATCATTTAGGG) were designed to amplify flanking sequences, representing the 16S-trnI-trnA-23S region of the tobacco plastome, for vector construction. PCR was carried out with 30 cycles of $45 \mathrm{~s}$ at $95{ }^{\circ} \mathrm{C}, 40 \mathrm{~s}$ at $50{ }^{\circ} \mathrm{C}$, and $2 \mathrm{~min}$ at $72{ }^{\circ} \mathrm{C}$, with a $5 \mathrm{~min}$ pre-denaturation before the first cycle at $95^{\circ} \mathrm{C}$ and a $10 \mathrm{~min}$ final extension at $72{ }^{\circ} \mathrm{C}$. The PCR product was inserted into vector pEASY Blunt Simple (Transgen Biotech Co., Ltd., Beijing, China) and verified by sequencing to generate pEASY-Nt. An expression cassette was obtained, as previously described [25]. The whole cassette was amplified by PCR and the product was inserted into the pEASY-Nt vector to form a new vector named pEASY-synth.

Codon optimization of the $b F G F$ encoding target gene was carried out using the software Synthetic Gene Designer (http://www.evolvingcode.net/codon/sgd/index.php). The 474bp optimized $b F G F$ gene was inserted into a multiple cloning site (MCS) to yield the final expression vector pXWL-Nt03. (Figure 1). Sequencing revealed that no errors had been introduced.

\subsection{Chloroplast Transformation and Homoplastomic Selection}

Tobacco chloroplast transformation was carried out according to the protocol previously described [40]. Briefly, young leaves of in vitro cultured tobacco plants were bombarded using PDS 1000/He biolistic particle delivery system (Bio-Rad, Hercules, CA, USA) with $50 \mathrm{mg}$ of $0.6 \mu \mathrm{m}$ gold particles coated with $10 \mu \mathrm{g}$ of plasmid DNA at $1100 \mathrm{psi}$. Putative transformants were regenerated in MS medium containing $500 \mathrm{mg} / \mathrm{L}$ spectinomycin at the first round of selection. The PCR-confirmed leaves of resistant shoots were cut into pieces and subjected to three additional regeneration cycles in selective medium. $\mathrm{T}_{1}$ seeds were harvested from $\mathrm{T}_{0}$ homoplastomic plants proved by molecular identification and sowed the seeds in pots until to $\mathrm{T}_{3}$ generation.

\subsection{Molecular Testing}

Total genomic DNA was extracted from fully expanded young leaves of both transplastomic plants and untransformed wild-type plants using the cetyltrimethylammonium bromide (CTAB) protocol [41]. PCR was carried out under the following conditions: $95{ }^{\circ} \mathrm{C}$ for $45 \mathrm{~s}, 50{ }^{\circ} \mathrm{C}$ for $40 \mathrm{~s}$, $72{ }^{\circ} \mathrm{C}$ for $2 \mathrm{~min}$; 35 cycles with a $5 \mathrm{~min}$ pre-denaturation before the first cycle at $95^{\circ} \mathrm{C}$ and a $10 \mathrm{~min}$ final extension at $72{ }^{\circ} \mathrm{C}$. The sequence of primer pair designed to check expression cassette was Ec1 (GGTCGGAACAAGTTGATAG) and Ec2 (CAGTAGAGTCTTTCAGTGGC), respectively. The expected PCR band will be $\sim 3.4 \mathrm{~kb}$ due to insertion of the foreign expression cassette.

Integration of the foreign expression cassette into the tobacco plastid genome was assessed by Southern blot. The total DNA extracted from young leaves was digested with Bam H I and Kpn I (New England Biolabs, Hitchin, UK) overnight at $37^{\circ} \mathrm{C}$ and subjected to $0.8 \%$ agarose gel electrophoresis, then transferred onto positive-charged Hybond- $\mathrm{N}^{+}$nylon membrane (Roche, Basel, Switzerland). Cross-link twice for $30 \mathrm{~s}$ each time with 3 min interval. Pre-hybridization and hybridization were carried with the DIG High Prime DNA Labeling and Detection Starter Kit II (Roche) according to the manufacturer's instructions. The DNA-fixed membrane was hybridized at $42{ }^{\circ} \mathrm{C}$ for $16 \mathrm{~h}$ with the probe in a hybridization oven before washing and visualization.

Total RNA was prepared using RNAiso Reagent (TaKaRa Co., Ltd., Dalian, China) and the manufacturer's instruction from four transgenic lines to test the mRNA transcriptional level by Northern blotting analysis. The gfp and $b F G F$ genes were amplified as probes. An amount of $5 \mu \mathrm{g}$ of RNA was loaded in each well and fractionated on a $2.0 \%$ denaturing agarose gel, and then transferred onto a nylon membrane for cross-linking. Labeled two probes were hybridized at $65^{\circ} \mathrm{C}$ for $16 \mathrm{~h}$ in a hybridization oven. Membrane was washed and visualized accordingly. 


\subsection{Western Blot Assay}

Expression of bFGF was measured by Western blot. Briefly, crude protein extracts were extracted from PCR-positive plants, separated by a 15\% SDS-PAGE gel, then transferred to a nitrocellulose membrane $(0.22 \mu \mathrm{m}$, Millipore, Darmstadt, Germany) using a trans-blot semi-dry electrophoretic transfer cell (200 mA, $30 \mathrm{~min}$, Bio-Rad). The nitrocellulose membrane was then saturated with 5\% bovine serum albumin (BSA) $(w / v)$ in TBS-Tween $20[25 \mathrm{mM}$ Tris- $\mathrm{HCl} \mathrm{pH} 7.6,0.15 \mathrm{M} \mathrm{NaCl}, 0.05 \%$ $(w / v)$ Tween-20] for $1 \mathrm{~h}$. The membrane was incubated with bFGF-directed antibody (1:100, Santa Cruz Biotechnology Inc., Dallas, TX, USA), prior to incubation with the secondary antibody (1:3000, goat anti-mouse IgG alkaline phosphatase conjugate, Novagen, Madison, WI, USA). Labeled proteins were visualized by adding a substrate BCIP/NBT (Roche).

\subsection{ELISA}

To measure the expression level of recombinant protein in transplastomic plants, total soluble protein was extracted from fully expanded leaves of both transformed and wild-type plants. The leaves were cut into pieces and grounded by liquid nitrogen, homogenized in PBS buffer (137 mM $\left.\mathrm{NaCl}, 2.7 \mathrm{mM} \mathrm{KCl}, 10 \mathrm{mM} \mathrm{Na}_{2} \mathrm{HPO}_{4}, 2 \mathrm{mM} \mathrm{KH}_{2} \mathrm{PO} 4\right)$. ELISA was performed using commercial anti-bFGF antibodies, and recombinant bFGF as standard (Sigma, St. Louis, MO, USA), as previously described [42]. Similarly, GFP expression was measured in young, mature and old leaves individually, and analyzed the data statistically. Wild-type plant was used as control.

Acknowledgments: We thank Nuo Xu for his kind help in Southern and Northern blot analysis. This research work was founded by Jilin provincial project (C42070501).

Author Contributions: Yun-Peng Wang, Zheng-Yi Wei, Jian Ma and Shao-Chen Xing designed the experiment. Yun-Peng Wang, Xiao-Fang Zhong, Chun-Jing Lin, Yan-Zhi Liu and Yu-Ying Zhang conducted the experiment. Yu-Ying Zhang and Yu-Hong Cai conducted statistical analysis. Yun-Peng Wang, Zheng-Yi Wei and Shao-Chen Xing wrote the paper.

Conflicts of Interest: The authors declare no conflict of interest.

\section{References}

1. Yamashita, T.; Yoshioka, M.; Itoh, N. Identification of a novel fibroblast growth factor, FGF-23, preferentially expressed in the ventrolateral thalamic nucleus of the brain. Biochem. Biophys. Res. Commun. 2000, 277, 494-498. [CrossRef] [PubMed]

2. Gospodarowicz, D.; Bialecki, H.; Greenburg, G. Purification of the fibroblast growth factor activity from bovine brain. J. Biol. Chem. 1978, 253, 3736-3743. [PubMed]

3. Lavandero, S.; Chappuzeau, A.; Sapag-Hagar, M.; Oka, T. In vivo and in vitro evidence of basic fibroblast growth factor action in mouse mammary gland development. FEBS Lett. 1998, 439, 351-356. [CrossRef]

4. Akita, S.; Akino, K.; Imaizumi, T.; Hirano, A. A basic fibroblast growth factor improved the quality of skin grafting in burn patients. Burns 2005, 31, 855-858. [CrossRef] [PubMed]

5. Zou, H.; Nie, X.H.; Zhang, Y.; Hu, M.; Zhang, Y.A. Effect of basic fibroblast growth factor on the proliferation, migration and phenotypic modulation of airway smooth muscle cells. Chin. Med. J. 2008, 121, 424-429. [PubMed]

6. Xiong, N.; Yang, H.; Liu, L.; Xiong, J.; Zhang, Z.; Zhang, X.; Jia, M.; Huang, J.; Zhang, Z.; Mohamed, A.A.; Lin, Z.; Wang, T. bFGF promotes the differentiation and effectiveness of human bone marrow mesenchymal stem cells in a rotenone model for parkinson's disease. Environ. Toxicol. Pharmacol. 2013, 36, 411-422. [CrossRef] [PubMed]

7. Jia, X.; Tian, H.; Tang, L.; Zheng, L.; Zheng, L.; Yang, T.; Yu, B.; Wang, Z.; Lin, P.; Li, X.; et al. High-efficiency expression of TAT-bFGF fusion protein in Escherichia coli and the effect on hypertrophic scar tissue. PLoS ONE 2015, 10, e0117448. [CrossRef] [PubMed]

8. Xie, J.X.; Feng, Y.; Yuan, J.M.; You, Z.D.; Lin, H.Y.; Lu, C.L.; Xu, J.J. Positive effects of bFGF modified rat amniotic epithelial cells transplantation on transected rat optic nerve. PLoS ONE 2015, 10, e0124713. [CrossRef] [PubMed] 
9. Gasparian, M.E.; Elistratov, P.A.; Drize, N.I.; Nifontova, I.N.; Dolgikh, D.A.; Kirpichnikov, M.P. Overexpression in Escherichia coli and purification of human fibroblast growth factor (FGF-2). Biochemistry. Biochemistry (Moscow) 2009, 74, 221-225. [CrossRef] [PubMed]

10. Song, J.A.; Koo, B.K.; Chong, S.H.; Kwak, J.; Ryu, H.B.; Nguyen, M.T.; Vu, T.T.; Jeong, B.; Kim, S.W.; Choe, H. Expression and purification of biologically active human FGF2 containing the b'a' domains of human PDI in Escherichia coli. Appl. Biochem. Biotechnol. 2013, 170, 67-80. [CrossRef] [PubMed]

11. Kwong, K.W.; Ng, K.L.; Lam, C.C.; Wang, Y.Y.; Wong, W.K. Authentic human basic fibroblast growth factor produced by secretion in Bacillus subtilis. Appl. Microbiol. Biotechnol. 2013, 97, 6803-6811. [CrossRef] [PubMed]

12. Barr, P.J.; Cousens, L.S.; Lee-Ng, C.T.; Medina-Selby, A.; Masiarz, F.R.; Hallewell, R.A.; Chamberlain, S.H.; Bradley, J.D.; Lee, D.; Steimer, K.S. Expression and processing of biologically active fibroblast growth factors in the yeast Saccharomyces cerevisiae. J. Biol. Chem. 1988, 263, 16471-16478. [PubMed]

13. Mu, X.; Kong, N.; Chen, W.; Zhang, T.; Shen, M.; Yan, W. High-level expression, purification, and characterization of recombinant human basic fibroblast growth factor in Pichia pastoris. Protein Express. Purif. 2008, 59, 282-288. [CrossRef] [PubMed]

14. Wu, X.; Kamei, K.; Sato, H.; Sato, S.I.; Takano, R.; Ichida, M.; Mori, H.; Hara, S. High-level expression of human acidic fibroblast growth factor and basic fibroblast growth factor in silkworm (Bombyx mori L.) using recombinant baculovirus. Protein Expr. Purif. 2001, 21, 192-200. [CrossRef] [PubMed]

15. Ding, S.H.; Huang, L.Y.; Wang, Y.D.; Sun, H.C.; Xiang, Z.H. High-level expression of basic fibroblast growth factor in transgenic soybean seeds and characterization of its biological activity. Biotechnol. Lett. 2006, 28, 869-875. [CrossRef] [PubMed]

16. An, N.; Ou, J.; Jiang, D.; Zhang, L.; Liu, J.; Fu, K.; Dai, Y.; Yang, D. Expression of a functional recombinant human basic fibroblast growth factor from transgenic rice seeds. Int. J. Mol. Sci. 2013, 14, 3556-3567. [CrossRef] [PubMed]

17. Nausch, H.; Huckauf, J.; Koslowski, R.; Meyer, U.; Broer, I.; Mikschofsky, H. Recombinant production of human interleukin 6 in Escherichia coli. PLoS ONE 2013, 8, e54933. [CrossRef] [PubMed]

18. Ahmad, N.; Mukhtar, Z. Green factories: Plastids for the production of foreign proteins at high levels. Gene Ther. Mol. Biol. 2013, 15, 14-29.

19. Bock, R. Genetic engineering of the chloroplast: Novel tools and new applications. Curr. Opin. Biotechnol. 2014, 26, 7-13. [CrossRef] [PubMed]

20. Sood, P.; Bhattacharya, A.; Sood, A. Problems and possibilities of monocot transformation. Biol. Plant. 2011, 55, 1-15. [CrossRef]

21. Goldstein, D.A. Tempest in a tea pot: How did the public conversation on genetically modified crops drift so far from the facts? J. Med. Toxicol. 2014, 10, 194-201. [CrossRef] [PubMed]

22. Daniell, H.; Singh, N.D.; Mason, H.; Streatfield, S.J. Plant-made vaccine antigens and biopharmaceuticals. Trends Plant Sci. 2009, 14, 669-679. [CrossRef] [PubMed]

23. Lössl, A.G.; Waheed, M.T. Chloroplast-derived vaccines against human diseases: Achievements, challenges and scopes. Plant Biotechnol. J. 2011, 9, 527-539. [CrossRef] [PubMed]

24. Lu, Y.; Rijzaani, H.; Karcher, D.; Ruf, S.; Bock, R. Efficient metabolic pathway engineering in transgenic tobacco and tomato plastids with synthetic multigene operons. Proc. Natl. Acad. Sci. USA 2013, 110, 623-632. [CrossRef] [PubMed]

25. Wei, Z.; Liu, Y.; Lin, C.; Wang, Y.; Cai, Q.; Dong, Y.; Xing, S. Transformation of alfalfa chloroplasts and expression of green fluorescent protein in a forage crop. Biotechnol. Lett. 2011, 33, 2487-2494. [CrossRef] [PubMed]

26. Kittiwongwattana, C.; Lutz, K.; Clark, M.; Maliga, P. Plastid marker gene excision by the phiC31 phage site-specific recombinase. Plant Mol. Biol. 2007, 64, 137-143. [CrossRef] [PubMed]

27. Magee, A.M.; Horvath, E.M.; Kavanagh, T.A. Pre-screening plastid transgene expression in Escherichia coli may be unreliable as a predictor of expression levels in chloroplast-transformed plants. Plant Sci. 2004, 166, 1605-1611. [CrossRef]

28. He, Y.; Ning, T.; Xie, T.; Qiu, Q.; Zhang, L.; Sun, Y.; Jiang, D.; Fu, K.; Yin, F.; Zhang, W.; et al. Large-scale production of functional human serum albumin from transgenic rice seeds. Proc. Natl. Acad. Sci. USA 2011, 108, 19078-19083. [CrossRef] [PubMed]

29. Sil, B.; Jha, S. Plants: The future pharmaceutical factory. Am. J. Plant Sci. 2014, 5, 319-327. [CrossRef] 
30. Mikschofsky, H.; Broer, I. Feasibility of Pisum sativum as an expression system for pharmaceuticals. Transgenic Res. 2012, 21, 715-24. [CrossRef] [PubMed]

31. Drake, M.P.; Vann, M.C.; Fisher, L.R. Influence of nitrogen application rate on the yield, quality, and chemical components of flue-cured tobacco, part II: Application method. Tob. Sci. 2015, 52, $26-34$. [CrossRef]

32. Apel, W.; Schulze, W.X.; Bock, R. Identification of protein stability determinants in chloroplasts. Plant J. 2010, 63, 636-650. [CrossRef] [PubMed]

33. Zhou, F.; Badillo-Corona, J.A.; Karcher, D.; Gonzalez-Rabade, N.; Piepenburg, K.; Borchers, A.-M.I.; Maloney, A.P.; Kavanagh, T.A.; Gray, J.C.; Bock, R. High-level expression of HIV antigens from the tobacco and tomato plastid genomes. Plant Biotechnol. J. 2008, 6, 897-913. [CrossRef] [PubMed]

34. Oey, M.; Lohse, M.; Kreikemeyer, B.; Bock, R. Exhaustion of the chloroplast protein synthesis capacity by massive expression of a highly stable protein antibiotic. Plant J. 2009, 57, 436-445. [CrossRef] [PubMed]

35. Oey, M.; Lohse, M.; Scharff, L.B.; Kreikemeyer, B.; Bock, R. Plastid production of protein antibiotics against pneumonia via a new strategy for high-level expression of antimicrobial proteins. Proc. Natl. Acad. Sci. USA 2009, 106, 6579-6584. [CrossRef] [PubMed]

36. Kuersten, S.; Goodwin, E.B. The power of the 3' UTR: Translational control and development. Nat. Rev. Genet. 2003, 4, 626-637. [CrossRef] [PubMed]

37. Mertens, N.; Remaut, E.; Fiers, W. Increased stability of phage T7g10 mRNA is mediated by either a 5'- or a 3'-terminal stem-loop structure. Biol. Chem. 1996, 377, 811-817. [PubMed]

38. Tengood, J.E.; Ridenour, R.; Brodsky, R.; Russell, A.J.; Little, S.R. Sequential delivery of basic fibroblast growth factor and platelet-derived growth factor for angiogenesis. Tissue Eng. Part A 2011, 17, 1181-1189. [CrossRef] [PubMed]

39. Marblestone, J.G.; Edavettal, S.C.; Lim, T.; Lim, P.; Zuo, X.; Butt, T.R. Comparison of SUMO fusion technology with traditional gene fusion systems: Enhanced expression and solubility with SUMO. Protein Sci. 2006, 15, 182-189. [CrossRef] [PubMed]

40. Wang, Y.P.; Wei, Z.Y.; Zhang, Y.Y.; Lin, C.J.; Zhong, X.F.; Wang, Y.L.; Ma, J.Y.; Ma, J.; Xing, S.C. Chloroplast-expressed MSI-99 in tobacco improves disease resistance and displays inhibitory effect against rice blast fungus. Int. J. Mol. Sci. 2015, 16, 4628-4641. [CrossRef] [PubMed]

41. Murray, M.G.; Thompson, W.F. Rapid isolation of high molecular weight plant DNA. Nucleic Acids Res. 1980, 8, 4321-4325. [CrossRef] [PubMed]

42. Wirth, S.; Calamante, G.; Mentaberry, A.; Bussmann, L.; Lattanzi, M.; Barañao, L.; Bravo-Almonacid, F. Expression of active human epidermal growth factor (hEGF) in tobacco plants by integrative and non-integrative systems. Mol. Breed. 2004, 13, 23-35. [CrossRef]

(c) 2015 by the authors; licensee MDPI, Basel, Switzerland. This article is an open access article distributed under the terms and conditions of the Creative Commons by Attribution (CC-BY) license (http:/ / creativecommons.org/licenses/by/4.0/). 